\title{
Identifikasi dan Deteksi Aktivitas Daya Hambat Bakteri Actinomycetes yang diisolasi dari Tanah Gambut di Desa Tajok Kayong Kalimantan Barat
}

\author{
Sri Lestari ${ }^{1}$, Mukarlina ${ }^{1}$, Rikhsan Kurniatuhadi ${ }^{1}$ \\ ${ }^{1}$ Program Studi Biologi, Fakultas MIPA, Universitas Tanjungpura,Prof. Dr. H. Hadari Nawawi, Pontianak, \\ Email korespondensi: sril26683@gmail.com
}

\begin{abstract}
Actinomycetes bacteria can grow well in soil media with acidic $\mathrm{pH}$ conditions such as peat soil. This study aims to determine the genus of Actinomycetes bacteria from peat soil. Sampling was done in Tajok Kayong Village, Ketapang Regency. Isolation was carried out using Pour Plate Method using specific media, namely SCA (Strach Casein Agar) media, while the activity detection of Actinomycetes bacteria was carried out on Eschericia coli pathogenic bacteria and Staphylococcus aureus using the streak-cross Method. Identification and characterization done it macroscopic, microscopic and biochemical. The results obtained 7 isolates of Actinomycetes bacteria from peat soil which is the genus Streptomyces.
\end{abstract}

Keywords: Identification, Detection, Actinomycetes, Peat Soil.

\section{PENDAHULUAN}

Actinomycetes merupakan bakteri yang dapat hidup di perairan maupun tanah. Bakteri Actinomycetes mampu menghasilkan senyawasenyawa aktif yang dapat digunakan sebagai antibakteri, antifungi, antikanker dan antitumor. Actinomycetes memiliki potensi besar untuk mensintesis metabolit sekunder bioaktif. Sekitar $70 \%$ antibiotik yang telah ditemukan dihasilkan oleh Actinomycetes (Alcamo, 1996).

Bakteri Actinomycetes dapat tumbuh pada media tanah dengan kondisi $\mathrm{pH}$ asam sampai $\mathrm{pH}$ basa dan bahan organik rendah. Tanah gambut memiliki karakter $\mathrm{pH}$ rendah, rasio $\mathrm{C} / \mathrm{N}$ yang tinggi dan mengandung bahan organik tinggi. Tanah gambut di Desa Tajok Kayong memiliki pH dalam kategori asam. Menurut Hikmatullah dan Sukarman (2007), wilayah Pontianak, Ketapang, Mempawah, dan Sambas memiliki tanah gambut yang bersifat asam. Menurut Mutalib et al. (1991) secara umum keasaman tanah gambut berkisar antara 3-5 dan semakin tebal bahan organik maka keasaman gambut meningkat.

Penelitian Actinomycetes pada tanah gambut telah dilakukan di daerah Riau dan Serawak Malaysia. Menurut Subagjo dan Widjaja (1998), tanah gambut di Riau memiliki pH 3 sampai 5, sedangkan pada tanah gambut Kalimantan Barat dan Serawak Malaysia memiliki pH tanah lebih asam yaitu 2 sampai 5. Menurut penelitian Lestari et al. (2014), dua puluh delapan isolat Actinomyctes dari tanah gambut di Kabupaten Kampar Riau mampu tumbuh pada pH 5-7.
Penelitian yang dilakukan Marta et al. (2016), menunjukkan keanekaragaman Actinomycetes yang berhasil diisolasi dari tanah gambut di desa Langkai Riau memiliki potensi sebagai penghasil antibiotik sebanyak 14 isolat, semua isolat merupakan golongan Streptomyces. Penelitian Jeffrey et al. (2011), di Serawak Malaysia berhasil memperoleh 40 isolat Actinomycetes dari tanah gambut dan dari semua isolat, 8 isolat memiliki potensi sebagai penghasil antibiotik. Isolat Actinomycetes yang ditemukan terdiri dari 7 genus Streptomyces.

Keberadaan Actinomycetes indigenus di tanah gambut Desa Tajok Kayong Kabupaten Ketapang Kalimantan Barat belum ada informasi. Tujuan dari penelitian ini adalah untuk mengetahui genera bakteri Actinomycetes yang diisolasi dari tanah gambut di Desa Tajok Kayong, Ketapang, Kalimantan Barat.

\section{BAHAN DAN METODE Waktu dan Tempat}

Penelitian dilaksanakan pada bulan Februari hingga Juni 2018. Lokasi pengambilan sampel tanah gambut dilakukan di Desa Tajok Kayong, Ketapang, Kalimantan Barat. Isolasi, karakterisasi dan identifikasi dilakukan di Laboratorium Mikrobiologi, Jurusan Biologi, Fakultas Matematika dan Ilmu Pengetahuan Alam, Universitas Tanjungpura. 


\section{Bahan}

Bahan-bahan yang diperlukan pada penelitian ini adalah agar, akuades steril, alkohol 70\%, $\mathrm{CaCO} 3$, Casein, cristal violet, $\mathrm{FeSO}_{4} \cdot 7 \mathrm{H}_{2} \mathrm{O}$, fruktosa, glukosa, hidrogen peroksida 3\%, innulin, iodium, isolat Eschericia coli DKA22, isolat Staphylococcus aureus $\mathrm{YKS} 12, \mathrm{~K}_{2} \mathrm{HPO}_{4}, \mathrm{KNO}_{3}$, mannitol, media Citrat Indol Motility (SIM), media Nutrient Agar (NA), media Simmon Citrat Agar (SCA), media Triple Sugar Iron (TSIA), media Urea Agar Best, methyle red, minyak imersi, $\mathrm{MgSO}_{4} \cdot 7 \mathrm{H}_{2} \mathrm{O}, \mathrm{NaCl}$, pepton, reagen Kovacs, safranin, Soluble starch, spiritus, sukrosa dan tanah gambut.

\section{Pembuatan dan Sterilisasi Media Starch-Casein Agar (SCA)}

Agar ditimbang sebanyak $15 \mathrm{~g}$, solubel starch $10 \mathrm{~g}$, $\mathrm{K}_{2} \mathrm{HPO}_{4} 2 \mathrm{~g}, \mathrm{KNO}_{3} 2 \mathrm{~g}, \mathrm{NaCl} 2 \mathrm{~g}$, Casein $0,3 \mathrm{~g}$, $\mathrm{MgSO}_{4} \cdot 7 \mathrm{H}_{2} \mathrm{O} 0,05 \mathrm{~g}, \mathrm{CaCo}_{3} 0,02 \mathrm{~g}, \mathrm{FeSO}_{4} \cdot 7 \mathrm{H}_{2} \mathrm{O}$ 0,01g. Bahan-bahan yang telah ditimbang dimasukkan kedalam gelas beker dan di tambahkan akuades sebanyak 1L, dipanaskan hingga mendidih, kemudian dimasukkan ke erlenmeyer, disterilisasi ke dalam autoklaf selama 15 menit dengan suhu $121^{\circ} \mathrm{C}$ tekanan 1atm (Atlas, 1946).

\section{Isolasi Actinomycetes}

Isolasi Actinomycetes dilakukan dengan metode tuang (Pour Plate), yaitu dengan cara sampel tanah gambut ditimbang sebanyak 1 gram kemudian di masukkan dalam $9 \mathrm{ml}$ akuades steril, dihomogenkan dengan menggunakan vortex. Suspensi sebanyak $1 \mathrm{ml}$, dimasukkan pada tabung reaksi pengenceran $10^{-1}$, diambil $1 \mathrm{ml}$ dari pengenceran $10^{-1}$, dimasukkan ke pengenceran $10^{-}$ ${ }^{2}$ dan dilakukan dengan cara yang sama sampai pengenceran $10^{-9}$, masing-masing setiap tingkat pengenceran diambil $1 \mathrm{ml}$ dimasukkan ke dalam cawan petri, selanjutnya dituangkan media StarchCasein Agar (SCA) ke dalam cawan petri dan dihomogenkan. Bakteri diinkubasi selama 72 jam pada suhu ruang $37^{\circ} \mathrm{C}$ (Waluyo, 2008).

\section{Pengamatan Karakter Morfologi Koloni Bakteri}

Pemeriksaan karakter morfologi koloni dilakukan dengan mengamati bentuk, tepian, elevasi, warna koloni dan ukuran diameter koloni. Karakter yang berbeda diberi kode (Krairitthichai dan Thongwai, 2005).

\section{Pemurnian Actinomycetes}

Actinomycetes yang sudah dilakukan pemeriksaan karakter morfologi yang berbeda dan diberi kode, selanjutnya dibuat 4 kuadran pada cawan petri, dituangkan media starch-casein agar (SCA) ke cawan petri. Masing-masing isolat bakteri ditanam ke dalam cawan petri secara streak plate kemudian diinkubasi selama 72 jam pada suhu $37^{\circ} \mathrm{C}$ (Waluyo, 2008).

\section{Uji biokimia}

Uji biokimia Actinomycetes meliputi pewarnaan gram, uji katalase, uji katabolisme karbohidrat dan produksi $\mathrm{H}_{2} \mathrm{~S}$, uji motilitas dan indol, uji sitrat, uji urease dan uji gula-gula.

\section{Deteksi Aktivitas Daya Hambat Bakteri Actinomycetes Terhadap Bakteri Escheria coli dan Staphylococcus aureus}

Deteksi aktivitas daya hambat dilakukan menggunakan metode cross streak (Kurniawati et al., 2015). Terlebih dahulu biakan murni bakteri patogen E. coli dan S. aureus diremajakan kembali sebelum digunakan, dengan cara di kultur pada media NA dan diinkubasi selama 24 jam. Isolat bakteri Actinomycetes digores pada satu sisi cawan seluas sepertiga cawan petri yang sudah berisi media NA padat dan diinkubasi selama 3 hari. Setelah 3 hari, bakteri E. coli dan $S$. aureus digoreskan pada sisi cawan yang kosong sepanjang $4,5 \mathrm{~cm}$ dengan arah tegak lurus terhadap goresan isolat dan Actinomycetes di inkubasi hingga tumbuh. Isolat bakteri Actinomycetes yang berpotensi antagonis akan ditunjukkan dengan terbentuknya zona bening di antara bakteri Actinomycetes dan bakteri E. coli dan S. aureus.

\section{Analisis Data}

Hasil karakterisasi dan uji daya hambat dianalisis secara deskriptif. Data disajikan dalam bentuk tabel dan gambar, dibandingkan dengan standar identifikasi menurut kunci Bergey's Manual of determinan Bacteriology, Bergey's Manual of Sistematic Bacteriology edisi ke-2, Journal Microbiology and Molecular Biology Reviews dan Journal of Applied Pharmaceutical Science.

\section{HASIL DAN PEMBAHASAN}

\section{Hasil}

Hasil karakterisasi isolat Actinomycetes diperoleh 7 isolat Actinomycetes dari tanah gambut di Desa Tajok Kayong, Kecamatan Nanga Tayap, Kabupaten Ketapang yaitu AKS1, AKS2, AKS3, AKS4, AKS5, AKS6 dan AKS7. Isolat bakteri tersebut mempunyai karakter koloni, sel dan fisiologis yang berbeda-beda. Hasil karakterisasi ketujuh isolat menunjukkan memiliki kemiripan dengan bakteri genus Streptomyces (Tabel 1 dan Gambar 1). 


\section{Protobiont (2019) Vol. 8 (1) : 13 - 19}

Tabel 1. Karakter-karakter koloni, sel dan fisiologis Isolat Actinomycetes dari Tanah Gambut di Desa Tajok Kayong, Ketapang, Kalimantan Barat

\begin{tabular}{|c|c|c|c|c|c|c|c|}
\hline Karakter & $\begin{array}{l}\text { Streptomyces } \\
\text { AKS1 }\end{array}$ & $\begin{array}{c}\text { Streptomyces } \\
\text { AKS2 }\end{array}$ & $\begin{array}{l}\text { Streptomyces } \\
\text { AKS3 }\end{array}$ & $\begin{array}{c}\text { Streptomyces } \\
\text { AKS4 }\end{array}$ & $\begin{array}{c}\text { Streptomyces } \\
\text { AKS5 }\end{array}$ & $\begin{array}{l}\text { Streptomyces } \\
\text { AKS6 }\end{array}$ & $\begin{array}{l}\text { Streptomyces } \\
\text { AKS7 }\end{array}$ \\
\hline Bentuk & Bulat & Bulat & Bulat & Bulat & Bulat & Bulat & Bulat \\
\hline Tepian & Bergelombang & Bergelombang & Bergelombang & Bergelombang & Bergelombang & Bergelombang & Filamen \\
\hline Elevasi & Rata & Cembung & Cembung & Umbonate & Umbonate & Cembung & Rata \\
\hline Permukaan & Tidak Licin & Tidak Licin & Tidak Licin & Tidak Licin & Tidak Licin & Tidak Licin & Tidak Licin \\
\hline Warna & Putih-Keabuan & Putih-Kekuningan & Putih & Putih-Kecoklatan & Putih-Kekuningan & Putih & Hitam \\
\hline Ukuran diameter koloni & $3,9 \mathrm{~mm}$ & $3,1 \mathrm{~mm}$ & $3,6 \mathrm{~mm}$ & $3,4 \mathrm{~mm}$ & $4,4 \mathrm{~mm}$ & $3,4 \mathrm{~mm}$ & $3,2 \mathrm{~mm}$ \\
\hline Sifat Gram & + & + & + & + & + & + & + \\
\hline Hifa Aerial & + & + & + & + & + & + & + \\
\hline Konidia & Chains dan Spiral & $\begin{array}{l}\text { Chains dan } \\
\text { Spiral } \\
\end{array}$ & Chains dan Spiral & $\begin{array}{l}\text { Chains dan } \\
\text { Spiral } \\
\end{array}$ & $\begin{array}{l}\text { Chains dan } \\
\text { Spiral }\end{array}$ & Chains dan Spiral & $\begin{array}{c}\text { Chains Dan Rectus- } \\
\text { Flexcibilis }\end{array}$ \\
\hline Glukosa & + & + & + & + & + & + & + \\
\hline Laktosa & - & - & + & - & + & + & - \\
\hline Sukrosa & - & - & + & - & + & + & - \\
\hline Fruktosa & + & + & + & - & + & + & + \\
\hline Mannitol & + & - & + & - & - & + & - \\
\hline Innulin & - & - & - & - & - & - & - \\
\hline Sitrat & - & - & + & + & + & - & + \\
\hline Gas & - & - & - & - & - & - & - \\
\hline $\mathrm{H}_{2} \mathrm{~S}$ & - & - & - & - & - & - & - \\
\hline Katalase & + & + & + & + & + & + & + \\
\hline Urease & + & + & + & + & + & - & + \\
\hline Indol & - & - & - & - & - & - & - \\
\hline Motilitas & - & - & - & - & - & - & - \\
\hline
\end{tabular}

Keterangan : (+) : mampu menghasilkan, (-) : tidak mampu menghasilkan, (mm) : Milimeter (Satuan Diameter Koloni) 


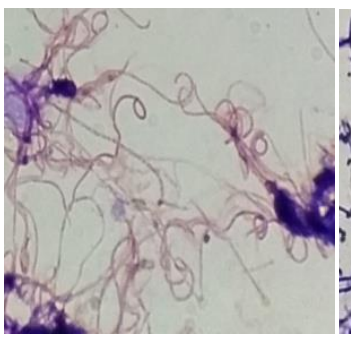

(a)

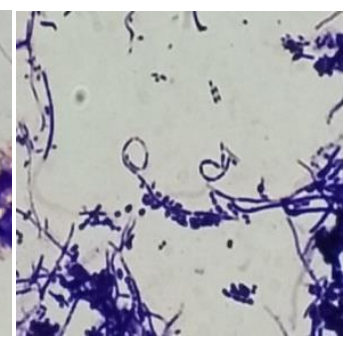

( b)

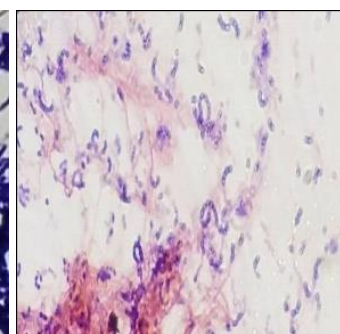

(c)

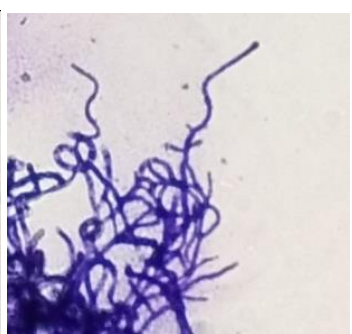

(d)

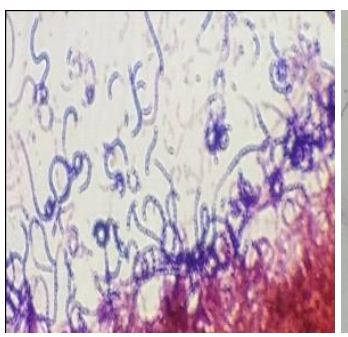

(e)

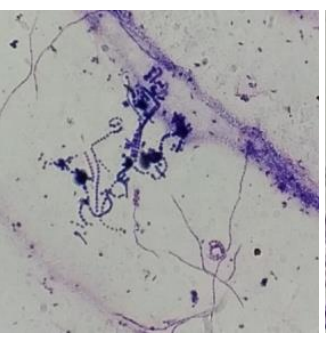

(f)

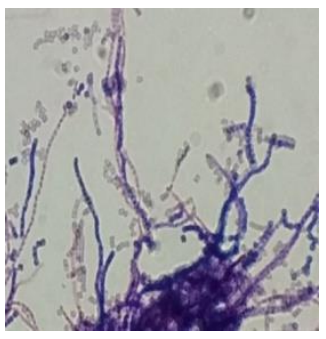

$(\mathrm{g})$

Gambar 1. Bentuk sel Streptomyces AKS1(a), Streptomyces AKS2(b), Streptomyces AKS3 (c), Streptomyces AKS4 (d), Streptomyces AKS5(d), Streptomyces AKS6(e) dan Streptomyces AKS7(f).

Hasil deteksi aktivitas daya hambat terhadap bakteri patogen E.coli dan S.aureus menunjukkan 5 isolat bakteri mampu menghambat pertumbuhan bakteri E. coli dan S.aureus dan 2 isolat bakteri hanya mampu menghambat pertumbuhan bakteri $S$. aureus saja (Tabel 2).

Tabel 2. Deteksi Aktivitas daya hambat Isolat Bakteri Actinomycetes terhadap bakteri E. coli dan $S$. aureus dari Tanah Gambut di Desa Tajok Kayong, Ketapang, Kalimantan Barat.

\begin{tabular}{ccc}
\multicolumn{4}{c}{ Kayong, Ketapang, Kalimantan } & E.coli & S. aureus \\
\hline isolat & + & + \\
Streptomycessp. AKS 1 & - & + \\
Streptomycessp. AKS 2 & + & + \\
Streptomycessp. AKS 3 & + & + \\
Streptomycessp. AKS 4 & + & + \\
Streptomycessp. AKS 5 & - & + \\
Streptomycessp. AKS 6 & + & + \\
Streptomycessp. AKS 7 & + & +
\end{tabular}

Keterangan: (+): mampu menghambat,( -): tidak mam menghambat.

Analisis fisik tanah gambut dari Desa Tajok Kayong menunjukkan suhu udara,suhu tanah dan kelembapan tanah termasuk dalam kategori sedang. Sedangkan analisis kandungan kimia tanah menujukkan $\mathrm{pH}$ tanah termasuk dalam kategori asam, kadar karbon dan nitrogen termasuk dalam kategori sedang, rasio kadar karbon dengan nitrogen dan kapasitas tukar kation termasuk dalam kategori rendah (Tabel 3).

\section{Pembahasan}

Isolat AKS1, AKS2, AKS3, AKS4, AKS5, AKS6 dan AKS7 memiliki kesamaan karakter genus Streptomyces. Karakter ketujuh isolat mempunyai permukaan koloni tidak licin dengan diameter koloni berukuran 3,1-4,4 mm. Ketujuh isolat memiliki miselium substrat bewarna putih yang berkembang menjadi miselium aerial bewarna putih keabuan pada AKS1, putih kekuningan pada AKS2 dan AKS5, putih kecoklatan pada AKS4 dan hitam pada AKS7. Sedangkan pada isolat AKS3 dan AKS6 masih bewarna putih (Tabel 4.1).

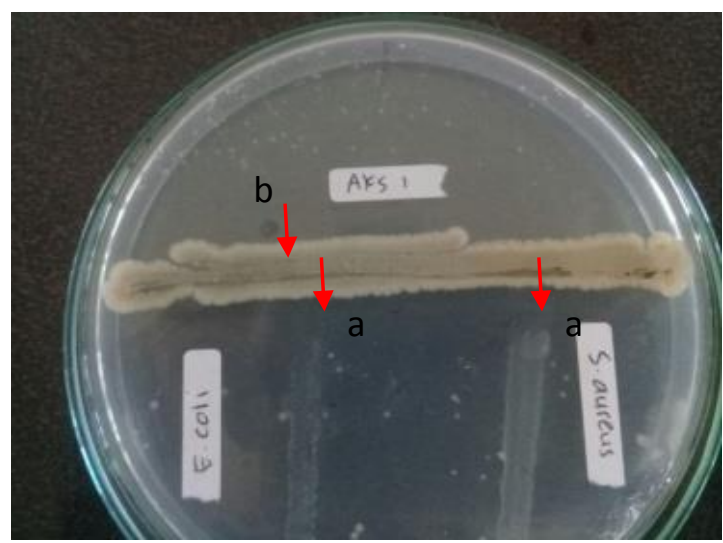

Gambar 2. Zona bening (ditunjukkan pada panah) deteksi aktivitas daya hambat bakteri Actinomycetes terhadap bakteri E. coli dan S. aureus (a); koloni isolat bakteri Actinomycetes (ditunjukkan pada panah) (b).

Holt et al. (1994), menunjukkan ciri khas genus Streptomyces yaitu permukaan koloni tidak licin, ukuran diameter koloni antara 1-10 mm, memiliki miselium aerial yang mengarah dari permukaan koloni ke udara. Miselium ini pada awalnya bewarna putih sampai coklat, lama-kelamaan berubah menjadi berwarna tertentu. Menurut Locci et al. (1983), miselium aerial dari anggota bakteri Streptomyces memiliki warna yang berbeda-beda seperti putih, abu-abu, kuning, oranye, lavender, biru, hijau, sampai hitam. 
Tabel 3. Karakter Analisis Fisik dan Kimia Tanah Gambut di Desa Tajok Kayong, Ketapang, Kalimantan Barat.

\begin{tabular}{|c|c|c|c|}
\hline Analisis & $\begin{array}{c}\text { Hasil } \\
\text { Analisis }\end{array}$ & Kategori & $\begin{array}{c}\text { Kisaran } \\
\text { Nilai } \\
\text { (LPT,1983 } \\
\text { ) }\end{array}$ \\
\hline Suhu Udara & $27,89^{\circ} \mathrm{C}$ & Sedang & $\begin{array}{c}20^{\circ} \mathrm{C}-30 \\
{ }^{\circ} \mathrm{C}\end{array}$ \\
\hline Suhu Tanah & $28,44^{\circ} \mathrm{C}$ & Sedang & $\begin{array}{c}20^{\circ} \mathrm{C}-30 \\
{ }^{\circ} \mathrm{C}\end{array}$ \\
\hline $\begin{array}{c}\text { Kelembapan } \\
\text { Tanah }\end{array}$ & $74,89 \%$ & Sedang & $60 \%-80 \%$ \\
\hline $\mathrm{pH}$ tanah & 5,08 & Asam & $4,5-5,5$ \\
\hline C-Organik & $2,14 \%$ & Sedang & $\begin{array}{l}2,01 \%- \\
3,00 \%\end{array}$ \\
\hline N-Total & $0,27 \%$ & Sedang & $\begin{array}{c}0,21 \%- \\
0,50 \%\end{array}$ \\
\hline Rasio $\mathrm{C} / \mathrm{N}$ & $7,93 \%$ & Rendah & $5 \%-10 \%$ \\
\hline KTK & $11,44 \%$ & Rendah & $5 \%-16 \%$ \\
\hline
\end{tabular}

Hasil pengamatan secara mikroskopis isolat AKS1, AKS2, AKS3, AKS4, AKS5, AKS6 dan AKS7 merupakan bakteri gram positif dan memiliki miselium aerial yang membentuk konidia rantai panjang (long chains). Isolat AKS1, AKS2, AKS3, AKS4, AKS5, AKS6 memiliki konidia tersusun seperti pilinan (spiral) dan isolat AKS7 tersusun lurus dan lentur (rectus-flexcibilis) (Gambar 4.14.7). Holt et al. (1994), menyatakan secara mikroskopis ciri khas genus Streptomyces yaitu memiliki filamen dan miselium aerial dengan konidia berantai panjang (long chains). Menurut Barka et al. (2016), penataan rantai konidia Streptomyces dikelompokkan menjadi empat yaitu lurus dan lentur (rectus-flexcibilis), putaran terbuka (relinaculum-apertum), seperti pilinan (spiral) dan vertikal (verticillate).

Hasil uji biokimia menunjukkan isolat AKS1, AKS2, AKS3, AKS4, AKS5, AKS6 dan AKS7 memiliki kesamaan karakter dengan genus Streptomyces yaitu spora non-motil, mampu menghasilkan enzim katalase, dapat mengasimilasi beberapa jenis gula, tidak mampu menghasilkan gas, $\mathrm{H}_{2} \mathrm{~S}$ dan indol (Tabel 4.1). Hal ini sesuai dengan pernyataan Holt et al. (1994), karakter kimia dari bakteri kelompok Actinomycetes khususnya genus Streptomyces memiliki spora non-motil dan menghasilkan enzim katalase, tidak menghasilkan gas, $\mathrm{H}_{2} \mathrm{~S}$ dan indol.

Isolat AKS1 dan AKS2 diduga memiliki kemiripan karakter dengan spesies $S$. mobaraensis menurut penelitian Nurkanto dan Agusta (2015), yaitu memiliki miselium aerial bewarna abu-abu, susunan konidia spiral, mampu mengasimilasi glukosa dan mannitol, tidak mampu mengasimilasi sitrat, mampu menghasilkan enzim katalase dan menghasilkan enzim urease.

Isolat AKS3 AKS4 dan AKS5 diduga memiliki kemiripan dengan spesies S.labedae menurut penelitian Nurkanto dan Agusta (2015), yaitu memiliki susunan konidia spiral, mampu mengasimilasi glukosa dan sitrat, serta dapat menghasilkan enzim katalase dan urease. Isolat AKS3, AKS4 dan AKS5 memiliki miselium aerial bewarna putih dan putih kecoklatan, berbeda dengan penelitian Nurkanto dan Agusta (2015), diperoleh hasil bahwa isolat S.labedae memiliki miselium aerial berwarna kuning.

Isolat AKS2 dan AKS6 diduga memiliki kemiripan dengan Streptomyces sp. TN256 menurut penelitian Smaoui et al. (2011), yaitu dapat mengamilasi glukosa, sukrosa, fruktosa dan sitrat, tetapi tidak dapat mengamilasi laktosa, namun pada AKS2 tidak dapat mengasimilasi laktosa dan sukrosa. Streptomyces sp. TN256 memiliki miselium aerial bewarna kuning, sedangkan isolat AKS2 dan AKS6 memiliki miselium aerial bewarna putih kekuningan dan putih.

Isolat AKS7 diduga memiliki kemiripan dengan $S$. Griseinus menurut Euanorasetr et al. (2010), yaitu memiliki susunan konidia rectus-flexcibilis. Isolat dapat mengamilasi glukosa, mannitol dan fruktosa, tetapi tidak dapat mengamilasi sukrosa dan laktosa. Isolat memiliki miselium aerial berwarna kuning kecoklatan, sedangkan isolat AKS7 memiliki miselium aerial berwarna hitam.

Hal ini sesuai dengan penelitian Esnard et al. (1995), menyatakan bahwa perbedaan warna koloni pada satu spesies bakteri Actinomycetes dapat disebabkan oleh perbedaan strain. Actinomycetes dalam satu spesies dapat memiliki karakter morfologi dan fisiologi yang berbeda. Penelitian Esnard et al. (1995), menyatakan bahwa $S$. hygroscopicus dan $S$. hygroscopicus subsp. decoyinus memiliki perbedaan warna koloni, kemampuan asimilasi gula, toleransi salinitas dan $\mathrm{pH}$, serta menyatakan bahwa resistensi beberapa jenis antibiotik, walaupun sekuen gen 16S rRNA kedua isolat tersebut identik.

Berdasarkan hasil deteksi aktivitas daya hambat dari 7 isolat yang berhasil diisolasi diperoleh 5 isolat yaitu AKS1, AKS3, AKS4, AKS5 dan AKS7 yang dapat menghambat pertumbuhan bakteri $E$. coli dan S. aureus, sedangkan 2 isolat yaitu AKS2 dan AKS6 hanya mampu menghambat bakteri $S$. aureus (Tabel 2). Kemampuan daya hambat 
bakteri ditunjukkan dengan adanya zona bening diantara isolat bakteri Streptomyces dengan isolat bakteri E. coli dan S. aureus (Gambar 2). Sesuai dengan pernyataan Barka et al. (2016), bahwa genus bakteri Actinomycetes yang merupakan produsen antibiotik utama yaitu genus Streptomyces. Berdasarkan penghambatan isolat bakteri streptomyces terhadap bakteri patogen $E$. coli dan $S$. aureus diduga menggunakan mekanisme antibiosis.

Perbedaan penghambatan bakteri uji oleh genus Streptomyces yang diisolasi dari tanah gambut Desa Tajok Kayong diduga bahwa isolat bakteri streptomyces memiliki spektrum kerja luas dan spektrum kerja sempit. Lima isolat memiliki spektrum kerja luas karena mampu menghambat bakteri gram negatif $E$. coli dan gram positif $S$. aureus., dua isolat memiliki spektrum kerja sempit karena hanya mampu menghambat bakteri gram positif $S$. aureus.

Perbedaan spektrum kerja isolat Streptomyces diduga karena adanya perbedaan metabolit sekunder yang disekresikan oleh masing-masing isolat Streptomyces dan perbedaan struktur selubung sel bakteri gram positif $E$. colidan gram negatif $S$. aureus. Sesuai dengan penelitian Ramadhan (2011) diperoleh isolat Streptomyces yang menghasilkan antibiotik tetrasiklin yang mampu menghambat bakteri E. coli dan S. aureus, dan isolat Streptomyces yang menghasilkan antibiotik eritromisin hanya mampu menghambat bakteri S. aureus. Menurut Jawetz et al. (2005), selubung sel gram negatif sangat kompleks dan strukturnya berlapis-lapis, sedangkan pada gram positif selubung selnya relatif sederhana dan terdiri dari 2-3 lapis, sehingga sel bakteri gram positif lebih mudah di rusak dan bakteri gram negatif tidak mudah dirusak oleh senyawa metabolit sekunder mikroorganisme lain.

Jenis Actinomycetes yang terdapat dalam tanah tertentu akan sangat dipengaruhi oleh lokasi geografis seperti suhu, jenis tanah, $\mathrm{pH}$ tanah, kandungan bahan organik, kelembaban tanah dan senyawa seperti C (carbon), N (nitrogen), rasio $\mathrm{C} / \mathrm{N}$. Menurut Prasad et al. (2015), bakteri Actinomycetes dapat hidup pada kisaran $\mathrm{pH}$ rendah 4,0-5,0 dan tumbuh optimum pada kisaran $\mathrm{pH}$ 6,58,0 , sedangkan Khan \& Williams (1975) menyatakan bahwa genus Streptomyces tumbuh optimum pada pH 5-9 dan toleran terhadap pH 3-4. Hal ini sesuai dengan hasil penelitian bahwa tanah gambut di desa Tajok Kayong memiliki $\mathrm{pH}$ asam yaitu 5,08, sehingga diperoleh isolat bakteri
Actinomycetes yang di dominasi oleh genus Streptomyces.

\section{DAFTAR PUSTAKA}

Alcamo, IE, 1996, Laboratory fundamentals of microbiology, Farmingdale: Addison Wesley publishing company, Ontario, Sidney.

Atlas, Ronald , M., 1946, Handbook of microbiological media, Ronald M. Atlas. 4th ed, Includes bibliographical references and index, ISBN 978-1-4398-CRC Press Taylor \& Francis Group.

Atmojo, SW, 2003, Peranan Bahan Organik Terhadap Kesuburan Tanah Dan Upaya Pengelolaannya, Universitas Sebelas Maret Surakarta.

Barka, EA, Vatsa, P,Sanchez, L, Vaillant, NG, Jacquard, C, Klenk, HP, Clément, C, 2016, 'Taxonomy, Physiology, and Natural Products of Actinobacteria', Microbiology and Molecular Biology Review, vol. 80 No.1, hal 20-22.

Esnard, J, Potter, TL, \& Zuckerman, BM, 1995, 'Streptomyces costaricanus sp. nov., isolated from Nematode-suppresive soil', International Journal of Systematic and Evolutionary Microbiology, vol.5, no.4, hal.775-779.

Euanorasetr , J, Arjaree, N, Srisurang, T, Takuya, N, Yusuhiro, I, \& Watanalai, P, 2010, 'Identification And Characterization Of Soil-Isolated Streptomyces Sje177 Producing Actinomycin', Journal Trop Med Public Health, vol. 41, no. 5, hal.11771187.

Hitmatullah \& Sukarman, 2007, 'Evaluasi Sifat-sifat Tanah Pada Landform Aluvial Di Kabupaten Donggala Sulawesi Tengah', Jurnal Tanah dan Iklim, vol.25, hal. 69-81.

Holt, JG, Krieg, NR, Sneath, PAH, Staley, JT, Williams, ST, 1994, Bergey's Manual of Determinative Bacteriology 9th Edition, Baltimor : Williams \& Wilkins.

Jawetz, Melnick \& Adelberg's, 2005, Mikrobiologi Kedokteran, diterjemahkan oleh Eddy Mudihardi, Kuntaman, Eddy Bagus Wasito, Ni Made Mertaniasih, Setio Harsono, \& Lindawati Alimsardjono, hal. 260-262, Salemba Medika, Jakarta.

Jeffrey, LSH, 2008, 'Isolation, characterization and identification of Actinomycetes from 
agriculture soils at Semongok, Sarawak', Afr J Biotechnol, vol.7, no.3, hal.697-3702.

Jeffrey, LSH, Norzaimawati, AN, \& Rosnah H, 2011, 'Prescreening of bioactivities from Actinomycetes isolated from forest peat soil of Sarawak', Journal Trop., Agric., and Fd Sc, vol.39, no.2, hal.245-253.

Khan, MR, \& Williams, ST, 1975, 'Studies on the ecology of Actinomycetes in soil, Distribution and characteristics of acidophilic Actinomycetes', Soil Biol. Biochem., vol.7, hal. 345348 .

Kurniawati, S, Mutaqin, KH,\& Giyant, 2015, 'Eksplorasi Dan Uji Senyawa Bioaktif Bakteri Agensia Hayati Untuk Pengendalian Penyakit Kresek Pada Padi”, J. Hpt Tropika, vol.15, no.2, hal.170-179.

Lestari, N, Odesia, Roza, M, \& Martina, M, 2014, 'Analisis Fisiologi Bakteri Lignoselulolitik dan Aktinomisetes Selulolitik dan Ligninolitik dari Tanah Gambut Desa Rimbo Panjang Kabupaten Kampar Sebagai Agen Biokompos', JOM, vol.1, No. 2, hal.571-580.

Locci, R, 1989, Streptomyces andrelaated genera, Bergey's Manual of Sistematic Bacteriology, baltimore, william \& wilkns Company, 2344-2508.

LPT (Lembaga Penelitian Tanah), 1983, Penuntun Analisa Fisika dan Kimia Tanah, Lembaga Penelitian Tanah, Badan Penelitian dan Pengembangan Pertanian.

Marta, Tetty, Linda, Napitupuli, L, \& Roza1, RM, 2016, Seleksi Aktinomisetes Isolat Lokal Dari Tanah Gambut Riau Sebagai Antipatogen Pada Streptococcus pyogenes, Prosiding Seminar Nasional from Basic Science to Comprehensive Education.

Mutalib, AA, Lim JS, Wong MH \& Koonvai L, 1991, Characterization, Distribution and Utilization of Peat In Malaysia, Proc., International Symposium on tropical peatland, Kuching, Serawak, Malaysia.

Nurkanto, A \& Agusta, A, 2015, 'Identifikasi Molekular dan Karakterisasi Morfo Fisiologi Actinomycetes Penghasil Senyawa Antimikroba', Jurnal Biologi Indonesia, vol.11, no.2, hal.195-203.

Prasad, M, Kumar, S, Kumar U, \& Anupama, 2015, 'Screening Of Endophytic Actinomycetes From Different Indigenous Medicinal Plants', European Journal Of
Experimental Biology, vol.5, no.4, Hal.714.

Ramadhan, H, 2011, 'Isolasi Actinomycetes Penghasil Antibiotik terhadap Escherichia Coli dan Staphylococcus Aureus dari Tanah Sawah, Jurnal Agro, vol.2, no.1, hal.50-64.

Smaoui, Slim, Mathieu, Florence, Elleuch, Lobna, Coppel, Yannick, Merlina, Georges, Rebai, K, Mellouli, Lofti, 2011, 'Taxonomy, purification and chemical characterization of four bioactive compounds from new Streptomyces sp.TN256 strain'. World Journal of Microbiology and Biotechnology, vol. 28, no.3, hal. 793-804.

Subagjyo, H, \& Widjaja, A, 1998, Peluang dan kendala penggunaan lahan rawa untuk pengembangan pertanian di Indonesia, kasus Sumatera Selatan dan Kalimantan Tengah, Pros., Pertemuan Pembahasan Komunikasi Hasil Penelelitian Tanah dan Agroklimat, Bogor.

Waluyo, L, 2008, Mikrobiologi Lingkungan, 266-270, UMM Press, Malang

William, ST, Goodfellow, M, Alderson, G, Wellington, EM, Sneath, PH, \&Sackin, MJ, 1983, 'Numerical classification of Streptomyces and related genera', Jurnal Gen Microbiol, vol.129, hal.1743 